\title{
EOItOR'S CORnER
}

In my final appearance as editor I find, fortunately, that most witticisms appropriate to a departing editor have already been uttered. It has been rewarding and it has been frustrating-like any other job, of course. The rewards pretty much speak for themselves and, I suspect, are best understood by others who have served in this capacity. Two frustrations, however, stand above all others, and will mar pleasant recollections. First, delinquent reviewers (and you know who you are) are a special bane, although my successor, Jeff Reid, is working on a scheme to diminish their impact on authors. Second, because space in the journal is limited, there has not been enough room to include many of the fine submissions to this office. This winnowing process will be less of a problem for Jeff with the initiation of our freshly minted sister journal, Latin American Antiquity.

The office of editor has been staffed by two exceptionally capable individuals. Assistant (now Managing) Editor Dr. Teresita Majewski has been colleague, copy editor, and office manager extraordinaire. Editorial Assistant Christopher B. Pulliam has managed the endless paperwork associated with tracking manuscripts, as well as the thankless task of systematizing the references cited, with more than commendable success.

Five associate and consulting editors labored outside the office. Susan C. Vehik's management of the Reviews and Book Notes must have seemed at times to be a task for the Danaïds, but she served without (conspicuously audible) complaint, as did Thomas F. Lynch in his capacity as editor for Current Research. Larry J. Zimmerman had the sad task of obtaining obituaries for departed members, and Michael J. O'Brien provided advice and council on many matters beyond the capabilities or competence of the editor, a role also played by Stephen E. Plog in his capacity as consultant in mathematics and statistics. The completion of each issue of the journal evoked for most of us an emotion that may be likened to that of Sisyphus as he watched the rock he'd laboriously pushed to the top of the hill roll once more to its base. My deepest gratitude is extended to each of these volunteer associates, to the Missouri Archaeological Society, which has provided office space and the loan of such equipment as a photocopy machine, and to the American Archaeology Division, University of Missouri-Columbia, which provided additional support.

Finally, it is my pleasure to pass the office of the editor-and the editorial pencil-along to J. Jefferson Reid, who already has made significant changes in the form and substance of American Antiquity. My very best wishes to him, his staff, the Sociefy, and the profession. In closing, please let me extend my gratitude to all of you for the privilege of serving you.

W. Raymond Wood Editor

American Antiquity, 55(2), 1990, p. 221.

Copyright $(1) 1990$ by the Society for American Archaeology 